\title{
Role of surface acidity on vanadia/silica catalysts used in the oxidative dehydrogenation of ethane
}

\author{
J. Le Bars, J.C. Vedrine and A. Auroux \\ Institut de Recherches sur la Catalyse, Laboratoire Propre du C.N.R.S., associé à l'Université \\ Claude Bernard, Lyon I, 2 Avenue Albert Einstein, 69626 Villeurbanne Cedex (France) \\ and \\ S. Trautmann and M. Baerns \\ Lehrstuhl für Technische Chemie, Ruhr-Universität Bochum, Postfach 102148, 4630 Bochum \\ (Germany)
}

\begin{abstract}
The oxidative dehydrogenation of ethane in ethene has been investigated in the 753-863 $\mathrm{K}$ temperature range over $\mathrm{V}_{2} \mathrm{O}_{5} / \mathrm{SiO}_{2}$ catalysts prepared by grafting or wet impregnation methods. The acidic features of fresh and used catalysts were studied by ammonia and pyridine adsorption using microcalorimetry and DRIFT spectroscopy. $\mathrm{V}_{2} \mathrm{O}_{5} / \mathrm{SiO}_{2}$ catalysts can be regarded as medium acidic materials. At the same conversion level of ethane, selectivity to ethene was favored by low $\mathrm{V}_{2} \mathrm{O}_{5}$ loadings. Ethane conversion increased with the vanadium content and the ammonia uptake of the $\mathrm{V}_{2} \mathrm{O}_{5} / \mathrm{SiO}_{2}$ catalysts. Some Brønsted-type sites disappeared in the course of the catalytic reaction, leading to minor changes in the acidic character of the catalysts.
\end{abstract}

Keywords: ethane, oxidative dehydrogenation, surface acidity, vanadia/silica.

\section{INTRODUCTION}

Partial oxidation of light alkanes has become a challenging research area in heterogeneous catalysis. For instance, ethane conversion has been widely studied [1-17]. Its dehydrogenation in the presence of oxygen is thermodynamically favoured due to water formation $\left(\Delta G^{\circ}=-136 \mathrm{~kJ} \mathrm{~mol}^{-1}\right.$ compared with $+101 \mathrm{~kJ} \mathrm{~mol}^{-1}$ in the absence of oxygen). Vanadium pentoxide is reported to be one of the main metal oxides used in the partial oxidation of hydrocarbons [18]. Its catalytic activity is usually modified when it is deposited on a support

Correspondence to: Dr. A. Auroux, Institut de Recherches sur la Catalyse, Laboratoire Propre du C.N.R.S., associé à l'Université Claude Bernard, Lyon I, 2 Avenue Albert Einstein, 69626 Villeurbanne Cedex (France). 
with new surface structures or solid solutions generated, which present different catalytic properties compared to those of the bulk oxide. The interaction between the support and vanadium oxide depends on many parameters including the acid-base properties of the support, the preparation method and the temperature of calcination.

Silica is one of the most widely available supports. Its high surface area is expected to allow large dispersing ability. The study of the interaction between vanadium pentoxide and silica has given rise to numerous works using various techniques, especially FT-IR of probe molecules [19,20], EXAFS-XANES [21,22], Laser Raman [23], XPS [24,25], ESR [26], ${ }^{51}$ V NMR [27,28], LTOC [29], TPR [30], and UV-Vis spectroscopy [31]. Bond and Tahir [32] recently provided a review about vanadium oxide monolayer catalysts including $\mathrm{V}_{2} \mathrm{O}_{5}$ / $\mathrm{SiO}_{2}$ systems. It turns out from these studies that vanadia and silica interact in a moderate way. Especially the difficulty of wetting silica with vanadium pentoxide is mentioned [21]. In previous work [33], we studied the oxidative dehydrogenation of ethane over bulk $\mathrm{V}_{2} \mathrm{O}_{5}$ and showed that only the redox properties of the catalyst, i.e. lattice oxygen migration and electron transfer can be taken into account for the mechanism of the reaction. In the present study we have investigated the reactivity of $\mathrm{V}_{2} \mathrm{O}_{5} / \mathrm{SiO}_{2}$ catalysts for the oxidative dehydrogenation of ethane into ethene and we have tried to correlate catalytic properties with adsorption features using microcalorimetry and infrared spectroscopy. Ammonia and pyridine have been used to probe the acidic behaviour of the surface. As a complement to the catalytic properties' determination and adsorption measurements, some additional characterizations have been performed by ESR, XPS, XRD and EDX-STEM analyses.

\section{EXPERIMENTAL}

\section{Catalysts preparation}

Two methods were applied.

First, impregnation of silica (Degussa, $380 \mathrm{~m}^{2} \mathrm{~g}^{-1}$ ) in aqueous neutral suspension with defined amounts of ammonium metavanadate $\mathrm{NH}_{4} \mathrm{VO}_{3}$, corresponding to $\mathrm{V}_{2} \mathrm{O}_{5}$ loadings from 1 to $20 \mathrm{wt}$. $\%$. Each suspension was stirred for $2 \mathrm{~h}$ at room temperature, then water was removed in a rotovapor at $373 \mathrm{~K}$. The samples were finally dried overnight at $393 \mathrm{~K}$ and heated at $823 \mathrm{~K}$ in an air flow for $5 \mathrm{~h}$.

Second, other $\mathrm{V}_{2} \mathrm{O}_{5} / \mathrm{SiO}_{2}$ catalysts were prepared by the grafting method [34], using vanadium oxytrichloride $\mathrm{VOCl}_{3}$ with anhydrous toluene as solvent. Silica (Degussa, $380 \mathrm{~m}^{2} \mathrm{~g}^{-1}$ ) was first dried at $393 \mathrm{~K}$ in a nitrogen flow and anhydrous toluene was then added. The suspension was stirred and heated at $343 \mathrm{~K}$ before the addition of the desired amount of $\mathrm{VOCl}_{3}$. The reactant mixture was then stirred overnight and filtered. The samples were finally dried at 
$393 \mathrm{~K}$ and heated in an air flow at $823 \mathrm{~K}$ for $5 \mathrm{~h}$. Chloride impurities, determined after heat treatment, did not exceed $0.03 \mathrm{wt} . \%$. Chemical analysis of the samples was carried out after calcination by atomic absorption spectroscopy (flame $\mathrm{N}_{2} \mathrm{O} / \mathrm{C}_{2} \mathrm{H}_{2}, \lambda=318 \mathrm{~nm}$ ). The samples were first dissolved in an acidic solution $\left(\mathrm{HF}+\mathrm{HNO}_{3}+\mathrm{H}_{2} \mathrm{SO}_{4}\right)$, then transferred in a diluted $\mathrm{HCl}$ solution $(0.6 \mathrm{M})$. The surface area of the catalysts was measured by the BET method using nitrogen adsorption at $77 \mathrm{~K}$. Prior to this determination, the samples were outgassed at $473 \mathrm{~K}$ for $3 \mathrm{~h}$.

\section{Activity measurements}

The catalysts were tested for the oxidative dehydrogenation of ethane using a fixed-bed continuous flow microreactor. All experiments were carried out with $10^{5} \mathrm{~Pa}$ total pressure. The experimental set-up has been described elsewhere [33]. Conversion is calculated as the ratio of the total formed products to the inlet ethane.

\section{Adsorption microcalorimetry measurements}

Adsorption microcalorimetry measurements were performed with a TianCalvet type differential heat flow microcalorimeter from Setaram, connected to a volumetric vacuum line equipped with a Barocel gauge [35]. The probe molecules, ammonia and pyridine, were previously outgassed by freeze-thaw pumping cycles. As standard activation, the catalysts were subjected to a heat treatment overnight under oxygen at $673 \mathrm{~K}$, and then evacuated at the same temperature for $2 \mathrm{~h}$. Successive known amounts of adsorbate were allowed to contact the catalyst, placed in the microcalometer cell maintained at $353 \mathrm{~K}$ to avoid excessive physisorption. The adsorption isotherm was determined in the pressure range of $0-200 \mathrm{~Pa}$. The differential and integral enthalpies of adsorption can be plotted versus the amount of probe molecule adsorbed.

\section{Infrared spectroscopy measurements}

The acidic features were also analyzed by infrared spectroscopy using a FTIR spectrometer from Perkin-Elmer (PE 1710) equipped with a DRIFT cell. The DRIFT cell (Spectra Tech) was connected to a gas line and could be subjected to heat treatments. Gas flows were regulated by Brooks mass flow controllers. Ammonia was used as probe molecule. Successive pulses of pure ammonia were admitted onto the samples at room temperature. Nitrogen $(99.999 \%$ purity) was used as carrier gas to remove the physisorbed species and for further desorptions at higher temperatures. Prior to any DRIFT measurements the catalysts were heated at $773 \mathrm{~K}$ under oxygen for $1 \mathrm{~h}$. DRIFT spectra usually resulted from the accumulation of 100 successive scans. The resolution of the 
interferometer was $8 \mathrm{~cm}^{-1}$. The background of the DRIFT cell was recorded at $423 \mathrm{~K}$ under a nitrogen flow using $\mathrm{KBr}$ as reference. The spectra result from the subtracted scans recorded at the same temperature and a transformation by the Kubelka-Munk function. Only adsorbed species due to chemisorbed ammonia are depicted. For better spectra presentation smoothing of the baseline was possible using computer programs.

\section{XPS measurements}

The surface composition of selected catalysts was determined by X-ray photoelectron spectroscopy using an $\mathrm{Al}$ cathode (Leybold Heraeus, LH 10 spectrometer). The samples were outgassed in the spectrometer chamber without any other treatment. Sample charging effect was corrected for with the $\mathrm{Si}$ $2 p$ signal at $103.4 \mathrm{eV}$. Peak areas were smoothed with Gauss convolution curves. The peak area of the $\mathrm{V} 2 \mathrm{p}_{3 / 2}, \mathrm{Si} 2 \mathrm{p}, \mathrm{O} 1 \mathrm{~s}$ and $\mathrm{C} 1 \mathrm{~s}$ signals were used to determine the relative surface concentrations of vanadium, oxygen, silicon and carbon, applying a sensitivity factor of $1.3(\mathrm{~V}), 0.66(\mathrm{O}), 0.27(\mathrm{Si})$ and $0.25(\mathrm{C})$.

\section{$X$-Ray diffraction analyses}

X-Ray diffraction analyses were carried out by means of a Philips PW 1070 goniometer with the $\mathrm{Cu} \mathrm{K} \alpha$ radiation under standard conditions.

\section{Electron spin resonance measurements}

ESR spectra of selected catalysts were recorded on a Varian E9 101 line spectrometer equipped with $\mathrm{X}$ band at $77 \mathrm{~K}$ in air. The spectra were calibrated with DPPH using a dual cell.

\section{Electron microscopy}

Typical aspects of the catalyst powders were examined using a high resolution transmission electron microscope (JEOL $100 \mathrm{CX}$ ). More detailed analyses were performed with a scanning transmission electron microscope (STEM) at high resolution (VG HB 501) equipped with EDX accessory for analytical analyses.

\section{RESULTS AND DISCUSSION}

\section{Physico-chemical characterizations}

Table 1 lists the physico-chemical characteristics of the $\mathrm{V}_{2} \mathrm{O}_{5} / \mathrm{SiO}_{2}$ catalysts. Vanadium pentoxide contents after heat treatment at $823 \mathrm{~K}$, as deter- 
TABLE 1

Physico-chemical characteristics of the $\mathrm{V}_{2} \mathrm{O}_{5} / \mathrm{SiO}_{2}$ catalysts

\begin{tabular}{|c|c|c|c|c|c|c|c|}
\hline \multirow[t]{2}{*}{ Catalysts } & \multirow{2}{*}{$\begin{array}{l}\mathrm{V}_{2} \mathrm{O}_{5} \\
\text { (wt.-\%) }\end{array}$} & \multirow{2}{*}{$\begin{array}{l}\text { Monolayer }^{a} \\
(\%)\end{array}$} & \multirow{2}{*}{$\begin{array}{l}\text { S BET } \\
\left(\mathrm{m}^{2} \mathrm{~g}^{-1}\right)\end{array}$} & \multicolumn{2}{|c|}{$\mathrm{V}: \mathrm{Si}$ (atomic ratio) } & \multicolumn{2}{|c|}{$\mathrm{V} 2 \mathrm{p}_{3 / 2}$} \\
\hline & & & & $\begin{array}{l}\text { Chemical } \\
\text { analysis }\end{array}$ & $\begin{array}{l}\text { XPS } \\
\text { analysis }\end{array}$ & $\begin{array}{l}\mathrm{BE} \\
(\mathrm{eV})\end{array}$ & FWMH \\
\hline \multirow{4}{*}{$\begin{array}{l}\text { Grafting } \\
\text { in toluene }\end{array}$} & 0.7 & 1.4 & 337 & - & - & - & \\
\hline & 4.0 & 9.5 & 278 & - & - & - & \\
\hline & 6.7 & 15.4 & 284 & $0.05: 1$ & $0.02: 1$ & 516.1 & 2.4 \\
\hline & 8.4 & 19.4 & 288 & - & - & - & - \\
\hline \multirow{4}{*}{$\begin{array}{l}\text { Impregnation } \\
\text { in water }\end{array}$} & 1.1 & 2.3 & 308 & $0.007: 1$ & $0.002: 1$ & 516.2 & 3.1 \\
\hline & 4.8 & 11.8 & 270 & $0.03: 1$ & $0.01: 1$ & 516.6 & 2.9 \\
\hline & 10.0 & 25.9 & 256 & $0.07: 1$ & $0.02: 1$ & 516.6 & 3.2 \\
\hline & 19.1 & 73.3 & 173 & $0.17: 1$ & $0.04: 1$ & 516.3 & 3.2 \\
\hline $\mathrm{V}_{2} \mathrm{O}_{5}^{b}$ & 100 & - & 12.8 & - & - & 516.9 & 1.8 \\
\hline
\end{tabular}

${ }^{a}$ Calculated from ref. 24 assuming monolayer of $\mathrm{V}_{2} \mathrm{O}_{5}$ on the surface with a cross-sectional area of $0.201 \mathrm{~nm}^{2}$.

${ }^{b}$ From ref. 33.

mined by chemical analyses, are very close to the theoretical values. This indicates that no sublimation of vanadium occurred during calcination. Theoretical monolayer coverages have been calculated from the surface area occupied by one single $\mathrm{V}_{2} \mathrm{O}_{5}$ molecule $\left(0.201 \mathrm{~nm}^{2}\right)$ [24]. The decrease in the specific area of the catalysts with increasing vanadium content can be attributed to mesopore plugging or sintering of the silica crystallites during the calcination at $823 \mathrm{~K}$, as confirmed by the variations of the t-surface: respectively 250,268 and $229 \mathrm{~m}^{2} \mathrm{~g}^{-1}$ for silica, 8.4 and $10.0 \mathrm{wt} .-\% \mathrm{~V}_{2} \mathrm{O}_{5} / \mathrm{SiO}_{2}$ samples. This decrease is favoured by large amounts of vanadium pentoxide and also when water is used as solvent in the preparation [36]. It is noteworthy that atomic $\mathrm{V} / \mathrm{Si}$ ratios given by XPS are smaller than those obtained by chemical analyses. The opposite was expected if silica particles had been fully covered by vanadium pentoxide. Since XPS is sensitive to the top 2-5 $\mathrm{nm}$ of a crystallite, it may be suggested that large $\mathrm{V}_{2} \mathrm{O}_{5}$ crystallites are formed. Such crystallites were detected by X-ray diffraction above $10 \mathrm{wt}$.- $\% \mathrm{~V}_{2} \mathrm{O}_{5}$. TEM analysis on a selected sample ( $\left.6.7 \mathrm{wt} . \% \mathrm{~V}_{2} \mathrm{O}_{5} / \mathrm{SiO}_{2}\right)$ showed that dispersion of vanadium is very heterogeneous. Small isolated vanadium clusters ( $3 \mathrm{~nm}$ in size) and limited patches of vanadium layers are present on the surface of silica granules (10-40 $\mathrm{nm}$ in size), in addition to needle-like crystallites and aggregates which are very rich in vanadium as revealed by EDX-STEM analyses. The EDXSTEM analyses finally showed that the V/Si ratio of the silica granules was slightly lower than that determined by chemical analysis.

Note that the $\mathrm{V} 2 \mathrm{p}_{3 / 2}$ peaks in XPS are broader for $\mathrm{V}_{2} \mathrm{O}_{5} / \mathrm{SiO}_{2}$ catalysts than 
for pure $\mathrm{V}_{2} \mathrm{O}_{5}$ (2.4 to $3.2 \mathrm{eV}$ against $1.8 \mathrm{eV}$ ). This may be due to a larger charging effect or more probably to more dispersed $\mathrm{V}_{2} \mathrm{O}_{5}$ particles corresponding to a more amorphous compound. ESR spectroscopy shows that $\mathrm{V}^{4+}$ ions $\left(\mathrm{d}^{1}\right)$ are present. The well resolved hyperfine structure of the spectrum corresponds to dispersed $\mathrm{V}^{4+}$ as vanadyl cations attached to terminal silanol groups or more probably as $\mathrm{V}^{4+}$ ions incorporated into the silica matrix since $\mathrm{V}^{4+}$ ions were not detected by XPS spectroscopy.

\section{Catalytic measurements}

Ethene selectivity against ethane conversion are compared on Fig. 1 for various $\mathrm{V}_{2} \mathrm{O}_{5} / \mathrm{SiO}_{2}$ catalysts. All samples were tested in similar experimental conditions using $100 \mathrm{mg}$ of catalyst and a total flow-rate of $50 \mathrm{~cm}^{3} \mathrm{~min}^{-1}$. The ethane and oxygen partial pressures were 7.3 and $0.93 \mathrm{kPa}$, respectively. $\mathrm{He}$ lium was used as diluent. The temperature of the reactor was varied between 753 and $863 \mathrm{~K}$. In that temperature range, the homogeneous reaction was checked and found to be negligible while pure silica was observed to be inefficient. Ethene and carbon monoxide were formed as reaction products. For a determined ethane conversion (e.g. $5 \%$ ), higher ethene selectivity is observed for low $\mathrm{V}_{2} \mathrm{O}_{5}$ loadings. During the catalytic run, the colour of the $\mathrm{V}_{2} \mathrm{O}_{5} / \mathrm{SiO}_{2}$ catalysts turned from yellow to white. This colour change is attributed to the desorption of water molecules at octahedrally coordinated vanadium centers $[20,31]$. Such a change in the coordination number, from octahedral to tetra-

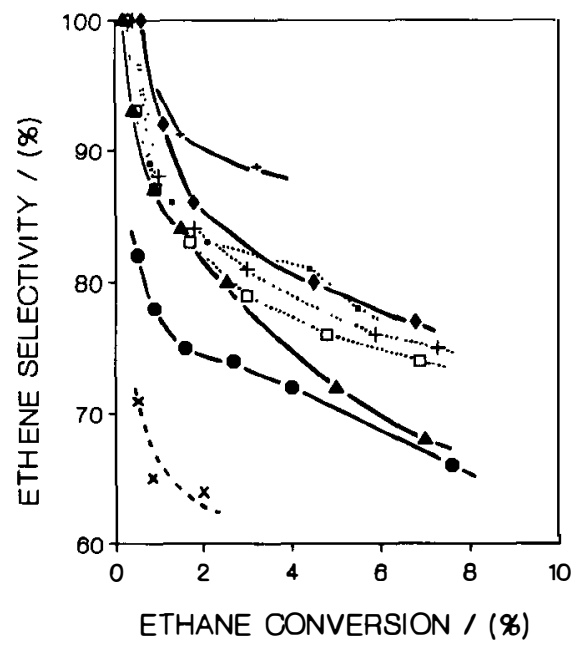

Fig. 1. Ethene selectivity as a function of ethane conversion on $\mathrm{V}_{2} \mathrm{O}_{5} / \mathrm{SiO}_{2}$ catalysts prepared by

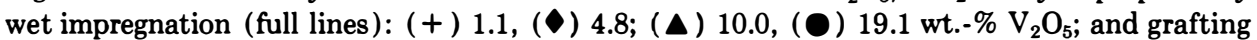
(dotted lines): $(\square) 4.0,(+)$ ) 6.7, ( $\square$ ) 8.4 wt.- $\% \mathrm{~V}_{2} \mathrm{O}_{5}$; and on bulk $\mathrm{V}_{2} \mathrm{O}_{5}(\times) .0 .100 \mathrm{~g}$ of catalyst; $F_{\mathrm{r}}=50 \mathrm{~cm}^{3} \mathrm{~min}^{-1} ; p\left(\mathrm{C}_{2} \mathrm{H}_{6}\right)=7.3 \mathrm{kPa} ; p\left(\mathrm{O}_{2}\right)=0.93 \mathrm{kPa}$. 
hedral was not observed on bulk vanadium pentoxide and may contribute to the enhancement of ethene selectivity on $\mathrm{V}_{2} \mathrm{O}_{5} / \mathrm{SiO}_{2}$ catalysts. Variations of ethene selectivities with conversion of ethane agree with previous reports $[8,10]$. At the same conversion level, $\mathrm{V}_{2} \mathrm{O}_{5} / \mathrm{SiO}_{2}$ is a more selective catalyst for ethene formation than bulk vanadium pentoxide, but its overall activity remains low. Some authors $[8,10]$ have reported the conversion of ethane to acetaldehyde using high contact time (conversion $<20 \%$ ), however with a low selectivity $(<10 \%)$. Courtine et al. [11] have reported on the (Mo-V-Nb$\mathrm{O}),(\mathrm{V}-\mathrm{O})$ and $(\mathrm{V}-\mathrm{P}-\mathrm{O})$ systems - the oxidative dehydrogenation of ethane in ethene at $623 \mathrm{~K}$ or its oxidation to acetic acid at lower temperatures. Concerning our measurements, only traces of acetaldehyde were detected, due to the low contact time we applied and the amount was too low to be clearly measured. The two series of catalysts present rather close values of activation energies for ethene formation as well as for ethane conversion (see Table 2). Note the decrease in activation energy values with vanadium loading while selectivity in ethene decreases.

Fig. 2 displays the variations of the rate of ethane conversion at $813 \mathrm{~K}$ versus the vanadium loading of the catalysts. The rate of ethane conversion expressed per gram of catalyst increases linearly with vanadium concentration up to ca. 5 wt.- $\% \mathrm{~V}_{2} \mathrm{O}_{5}$. Above that loading, the activity increases less than that the vanadium loading could induce. This is obviously due to a lower dispersion, more vanadium atoms are inserted in a vanadium pentoxide lattice and are not available for the reaction. It is also worth noting that the catalysts prepared by grafting exhibit slightly higher activity than samples prepared by aqueous impregnation.

The rate of ethene formation at $808 \mathrm{~K}$ on the $4.8 \mathrm{wt} .-\% \mathrm{~V}_{2} \mathrm{O}_{5} / \mathrm{SiO}_{2}$ catalyst is plotted against the partial pressure of oxygen on Fig. $3 \mathrm{a}$ and ethane on Fig. $3 \mathrm{~b}$. A first-order relation with ethane and low oxygen partial pressures are

TABLE 2

Summary of activation energies for ethane oxidative dehydrogenation

\begin{tabular}{llll}
\hline $\begin{array}{l}\mathrm{V}_{2} \mathrm{O}_{5} / \mathrm{SiO}_{2} \\
\text { catalysts }\end{array}$ & $\begin{array}{l}\mathrm{V}_{2} \mathrm{O}_{5} \\
(\text { wt.-\% })\end{array}$ & $\begin{array}{l}E_{\mathrm{a}} \mathrm{C}_{2} \mathrm{H}_{6} \\
\left(\mathrm{~kJ} \mathrm{~mol}^{-1}\right)\end{array}$ & $\begin{array}{l}E_{\mathrm{a}} \mathrm{C}_{2} \mathrm{H}_{4} \\
\left(\mathbf{k J ~ m o l}^{-1}\right)\end{array}$ \\
\hline $\begin{array}{l}\text { Grafting in } \\
\text { toluene }\end{array}$ & 0.7 & $170 \pm 15$ & $170 \pm 15$ \\
& 4.0 & $142 \pm 10$ & $132 \pm 20$ \\
& 6.7 & $142 \pm 20$ & $137 \pm 10$ \\
Impregnation & 8.4 & $153 \pm 10$ & $123 \pm 5$ \\
in water & 1.0 & $193 \pm 15$ & $193 \pm 15$ \\
& 4.8 & $139 \pm 7$ & $140 \pm 15$ \\
& 10.0 & $140 \pm 5$ & $139 \pm 15$ \\
& 19.1 & $128 \pm 15$ & $122 \pm 10$ \\
\hline
\end{tabular}




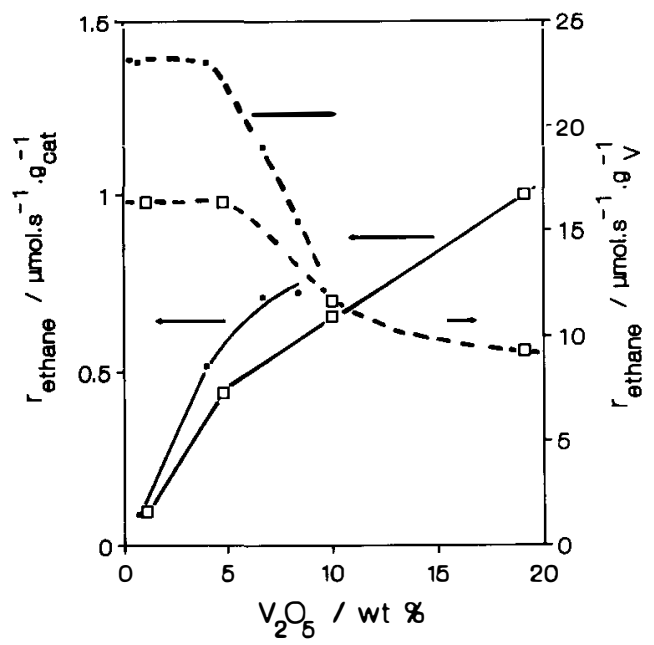

Fig. 2. Ethane oxidative dehydrogenation rate at $813 \mathrm{~K}$ per gram of catalyst (full lines) and per gram of vanadium (dotted lines) as a function of $\mathrm{V}_{2} \mathrm{O}_{5}$ content of the $\mathrm{V}_{2} \mathrm{O}_{5} / \mathrm{SiO}_{2}$ catalysts prepared by: ( $\square$ ) wet impregnation, ( $\square$ ) grafting. $0.100 \mathrm{mg}$ of catalyst; $F_{\mathrm{r}}=50 \mathrm{~cm}^{3} \cdot \mathrm{min}^{-1}$; $p\left(\mathrm{C}_{2} \mathrm{H}_{6}\right)=0.7 \mathrm{kPa} ; p\left(\mathrm{O}_{2}\right)=0.93 \mathrm{kPa}$.

observed. The rate of formation of ethene tends to zero order at high oxygen partial pressures. A typical redox scheme can be thus suggested:

$\mathrm{C}_{2} \mathrm{H}_{6}+\mathrm{ZO} \stackrel{k_{\mathrm{r}}}{\longrightarrow} \mathrm{C}_{2} \mathrm{H}_{4}+\mathrm{Z}+\mathrm{H}_{2} \mathrm{O}$

$2 \mathrm{Z}+\mathrm{O}_{2} \stackrel{k_{0}}{\longrightarrow} 2 \mathrm{ZO}$

where $\mathrm{ZO}$ and $\mathrm{Z}$ respectively present an oxidized and a reduced site. $k_{\mathrm{r}}$ Is the rate constant of the reduction of $\mathrm{ZO}$ by ethane to give ethene while $k_{\mathrm{o}}$ is the rate constant of the oxidation of the reduced site $Z$. From that scheme and assuming the steady-state approximation, we obtain the following equation:

$v=\frac{k_{\mathrm{r}} k_{\mathrm{o}} p\left(C_{2} H_{6}\right) p\left(\mathrm{O}_{2}\right)}{k_{\mathrm{r}} p\left(\mathrm{C}_{2} \mathrm{H}_{6}\right)+k_{\mathrm{o}} p\left(\mathrm{O}_{2}\right)}$

which can be transformed in eqn. (4):

$\frac{1}{v}=\frac{1}{k_{\mathrm{o}} p\left(\mathrm{O}_{2}\right)}+\frac{1}{k_{\mathrm{r}} p\left(\mathrm{C}_{2} \mathrm{H}_{6}\right)}$

Eqn. (4) allowed $k_{\mathrm{r}}$ and $k_{\mathrm{o}}$ to be determined at $808 \mathrm{~K}$ :

$$
\begin{aligned}
& k_{\mathrm{r}}=8.5 \times 10^{-8} \mathrm{~mol} \mathrm{~s}^{-1} \mathrm{~g}^{-1} \mathrm{kPa}^{-1} \\
& k_{\mathrm{o}}=1.3 \times 10^{-6} \mathrm{~mol} \mathrm{~s}^{-1} \mathrm{~g}^{-1} \mathrm{kPa}^{-1}
\end{aligned}
$$

The error in the determination of the rate constants is estimated to be within 

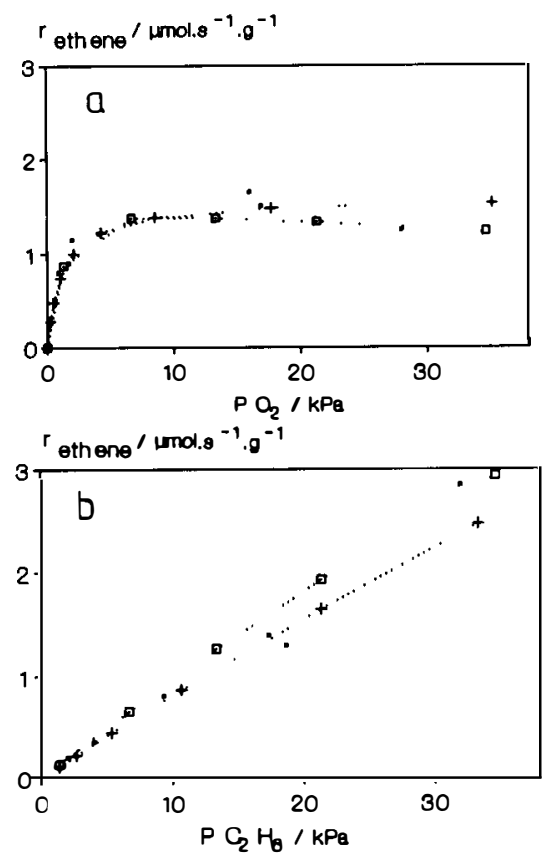

Fig. 3. Rate of ethene formation at $808 \mathrm{~K}$ as a function of oxygen partial pressure (a) $\left(p\left(\mathrm{C}_{2} \mathrm{H}_{6}\right)=18.7 \mathrm{kPa}\right)$, and as a function of ethane partial pressure $(\mathrm{b})\left(p\left(\mathrm{O}_{2}\right)=14.7 \mathrm{kPa}\right)$.

Experimental data; $(+)$ calculated data from the redox model; $(\square)$ calculated datafrom the redox model with competitive adsorption between ethane and oxygen. $0.100 \mathrm{~g}$ of $4.8 \mathrm{wt}$. $\% \mathrm{~V}_{2} \mathrm{O}_{5} / \mathrm{SiO}_{2}$ catalyst; $F_{\mathrm{r}}=50 \mathrm{~cm}^{3} \mathrm{~min}^{-1}$.

$8 \%$. Typical deviations of $10 \%$ were observed between experimental and calculated values of the rate of ethene formation. Larger deviations (25\%) are found for high partial pressures of ethane and oxygen which is possibly due to competitive adsorption between ethane and oxygen, leading to inhibition of ethene formation at high oxygen partial pressure according to the scheme:

$\mathrm{C}_{2} \mathrm{H}_{6}+\mathrm{ZO} \stackrel{k_{\mathrm{r}}^{\prime}}{\longrightarrow} \mathrm{C}_{2} \mathrm{H}_{4}+\mathrm{Z}+\mathrm{H}_{2} \mathrm{O}$

$2 \mathrm{Z}+\mathrm{O}_{2} \stackrel{k_{0}^{\prime}}{\longrightarrow} 2 \mathrm{ZO}$

$2 \mathrm{ZO}+\mathrm{O}_{2} \stackrel{K}{\rightleftharpoons} 2 \mathrm{ZO}_{2}$

where $\mathrm{ZO}_{2}$ sites are supposed to be inactive for ethene formation. Rate eqn. (8) can be derived from reactions (5), (6) and (7):

$v=\frac{k_{\mathrm{r}}^{\prime} k_{\mathrm{o}}^{\prime} p\left(\mathrm{C}_{2} \mathrm{H}_{6}\right) p\left(\mathrm{O}_{2}\right)}{k_{\mathrm{r}}^{\prime} p\left(\mathrm{C}_{2} \mathrm{H}_{6}\right)+\left(k_{\mathrm{o}}^{\prime} p\left(\mathrm{O}_{2}\right)\left(1+K^{1 / 2} p\left(\mathrm{O}_{2}\right)^{1 / 2}\right)\right.}$ 
The resolution of eqn. (8) leads to the following values of $k_{\mathrm{r}}^{\prime}, k_{\mathrm{o}}^{\prime}$ and $K$ :

$k_{\mathrm{r}}^{\prime}=1.5 \times 10^{-7} \mathrm{~mol} \mathrm{~s}^{-1} \mathrm{~g}^{-1} \mathrm{kPa}^{-1}$

$k_{\mathrm{o}}^{\prime}=1.2 \times 10^{-6} \mathrm{~mol} \mathrm{~s}^{-1} \mathrm{~g}^{-1} \mathrm{kPa}^{-1}$

$K=3 \times 10^{-2} \mathrm{kPa}^{-1}$

Rate eqn. (8) fits the experimental kinetic data well at high partial pressures of ethane and oxygen. Errors in the $K$ and $k_{\mathrm{r}}^{\prime}$ values were estimated around $30 \%$, and $10 \%$ for $k_{\mathrm{o}}^{\prime}$. However, in both models, according to the values of the calculated rate constants, the limiting step of ethane oxidative dehydrogenation turns out to be the reduction of oxidized sites by ethane. Thus, the $\mathrm{V}_{2} \mathrm{O}_{5}$ / $\mathrm{SiO}_{2}$ catalyst can be considered to work in a rather oxidized state in the course of the reaction.

Acidity measurements on fresh catalysts

\section{Microcalorimetry measurements-ammonia adsorption}

The differential enthalpies of ammonia adsorption are presented in Fig. 4 versus the ammonia uptake on the two series of $\mathrm{V}_{2} \mathrm{O}_{5} / \mathrm{SiO}_{2}$ catalysts. We here report the ammonia uptake in $\mu \mathrm{mol} \mathrm{m}^{-2}$ of catalyst. Concerning the samples prepared by aqueous wet impregnation (right-hand side of Fig. 4), the ammonia uptakes and enthalpies of adsorption respectively reveal that both number and strength of acid sites increase with vanadium content. The lack of acidity of silica after outgassing at $673 \mathrm{~K}$ has already been reported [35] and we have previously measured the acidic features of bulk vanadium pentoxide

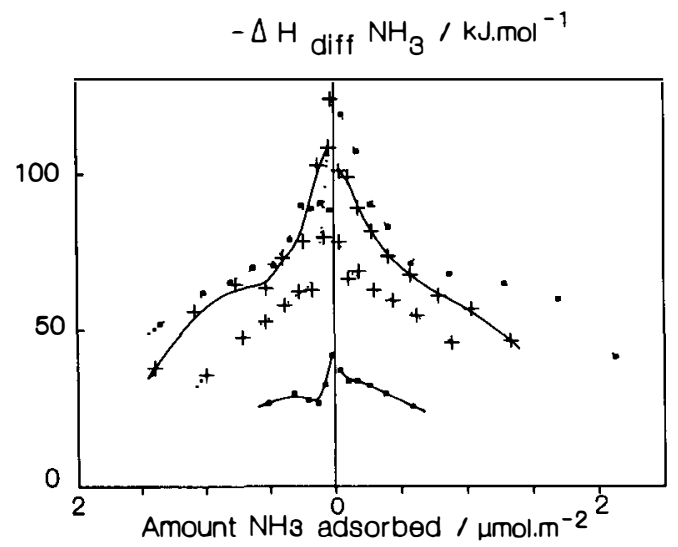

Fig. 4. Differential enthalpies of adsorption of ammonia at $353 \mathrm{~K}$ as a function of coverage on $\mathrm{V}_{2} \mathrm{O}_{5} / \mathrm{SiO}_{2}$ catalysts prepared by wet impregnation (right-hand side): $(-\square-) 1.1,(\cdots+\cdots) 4.8$, $(-+-) 10.0,(\cdots+\cdots) 19.1 \mathrm{wt} . \% \mathrm{~V}_{2} \mathrm{O}_{5}$; and grafting (left-hand side): $(-\square-) 0.7,(\cdots+\cdots)$ 4.0, $(-+-) 6.7,(\cdots-\cdots) 8.4$ wt. $\% \mathrm{~V}_{2} \mathrm{O}_{5}$. 


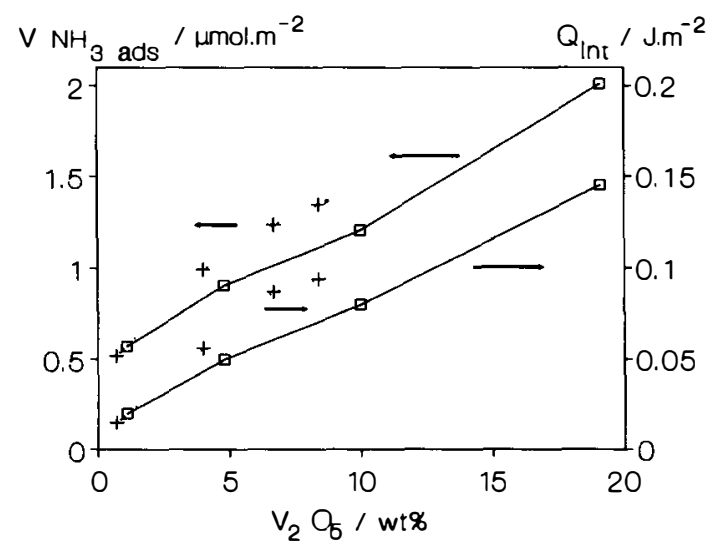

Fig. 5. Ammonia uptake and integral enthalpies of adsorption at $353 \mathrm{~K}$ as a function of $\mathrm{V}_{2} \mathrm{O}_{5}$ content on $\mathrm{V}_{2} \mathrm{O}_{5} / \mathrm{SiO}_{2}$ catalysts prepared by: $(-\square$ - ) wet impregnation, $(\cdots+\cdots)$ grafting.

[33]. That bulk oxide presents a much lower specific area $\left(13 \mathrm{~m}^{2} \mathrm{~g}^{-1}\right)$ than $\mathrm{V}_{2} \mathrm{O}_{5} / \mathrm{SiO}_{2}$ catalysts ( 173 to $300 \mathrm{~m}^{2} \mathrm{~g}^{-1}$ ). We previously reported an initial enthalpy of ammonia adsorption of $67 \mathrm{~kJ} \mathrm{~mol}^{-1}$ on bulk vanadium pentoxide [33]. Higher values of initial enthalpy of ammonia adsorption have been measured for the $\mathrm{V}_{2} \mathrm{O}_{5} / \mathrm{SiO}_{2}$ catalysts ( 78 to $124 \mathrm{~kJ} \mathrm{~mol}^{-1}$ ), except for the 0.7 and 1.1 wt. $\% \mathrm{~V}_{2} \mathrm{O}_{5} / \mathrm{SiO}_{2}$ samples which show weak acidity. Note that ammonia adsorption on pure silica has been reported to give rise to a plateau at $35 \mathrm{~kJ}$ $\mathrm{mol}^{-1}[35]$. New surface sites are formed by deposition of vanadium species on silica, which present more acid strength than pure silica and bulk vanadium pentoxide. Similar trends in strength distributions and the number of acid sites have been found for the $\mathrm{V}_{2} \mathrm{O}_{5} / \mathrm{SiO}_{2}$ catalysts prepared by the grafting method (left-hand side of Fig. 4).

If we consider the overall chemisorbed ammonia volume (at $p\left(\mathrm{NH}_{3}\right)=66.7$ $\mathrm{Pa}$ ) versus the vanadium content (Fig. 5 ), the population of the titrated acid sites is slightly higher for the grafted $\mathrm{V}_{2} \mathrm{O}_{5} / \mathrm{SiO}_{2}$ catalysts than for the samples prepared by wet aqueous impregnation. A linear relation was also observed between the integral enthalpy of ammonia adsorption and the vanadium content of the catalysts. At similar vanadium concentrations, the $\mathrm{V}_{2} \mathrm{O}_{5} / \mathrm{SiO}_{2}$ catalysts prepared by grafting present slightly higher values of integral enthalpies of ammonia adsorption in agreement with their more important acidic populations. The number of acid sites of pure silica and then the associated integral enthalpy of ammonia adsorption can be determined from the intersection of the plots with the origin.

\section{Pyridine adsorption}

Due to its lower basicity $\left(\mathrm{p} K_{\mathrm{a}}=5.5\right)$, pyridine is a more selective probe molecule than ammonia $\left(\mathrm{p} K_{\mathrm{a}}=9.25\right)$ and can therefore be applied to draw more 


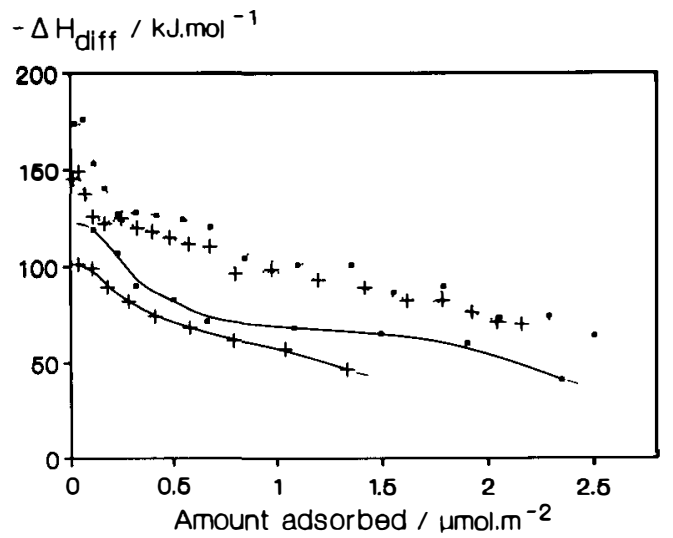

Fig. 6. Differential enthalpies of adsorption at $353 \mathrm{~K}$ as a function of ammonia (full lines) and pyridine (dotted lines) coverages on $\mathrm{V}_{2} \mathrm{O}_{5} / \mathrm{SiO}_{2}$ catalysts: $(+) 10$ and ( $\left.\boldsymbol{\square}\right) 19.1$ wt.- $\% \mathrm{~V}_{2} \mathrm{O}_{5}$.

finely the acidic features of a catalytic surface. In the domain of high acidic strength, two $\mathrm{V}_{2} \mathrm{O}_{5} / \mathrm{SiO}_{2}$ catalysts (10 and 19.1 wt.- $\% \mathrm{~V}_{2} \mathrm{O}_{5}$ ) have been subjected to pyridine adsorption. Differential enthalpies of adsorption of pyridine are compared on Fig. 6 to those obtained by ammonia adsorption on the same catalysts, versus the coverage.

Pyridine is found to give rise to higher adsorption enthalpies and chemisorbed uptakes than ammonia, which is quite surprising according to the $\mathrm{p} K_{\mathrm{a}}$ of the two probes. However, pyridine has a lower vapour pressure than ammonia and its enthalpy of liquefaction at $353 \mathrm{~K}$ is $37 \mathrm{~kJ} \mathrm{~mol}^{-1}$ instead of $15 \mathrm{~kJ}$ $\mathrm{mol}^{-1}$ for ammoniá. Therefore, on the one hand, the contribution of the enthalpy of liquefaction of pyridine to the measured enthalpy of adsorption is more relevant than in the case of ammonia adsorption. On the other hand, it can be considered that chemisorption of pyridine is over for a partial pressure much lower than $66.7 \mathrm{kPa}$, which usually corresponds to the end of ammonia chemisorption. Pyridine shows three acid site populations: one of them with adsorption enthalpies above $125 \mathrm{~kJ} \mathrm{~mol}^{-1}$, then some medium sites between 125 and $100 \mathrm{~kJ} \mathrm{~mol}^{-1}$ and a third population of weak sites in the $100-70 \mathrm{~kJ}$ $\mathrm{mol}^{-1}$ range. These populations respectively represent 10,25 and $65 \%$ of the overall pyridine uptake. Only two acid site distributions can be extracted from the differential adsorption enthalpies of ammonia.

\section{DRIFT measurements}

Base adsorption by infrared spectroscopy using the diffuse reflectance mode (DRIFT) allows the identification of the acidic populations of the surface and therefore is a suitable tool to complement the microcalorimetry measurements. Ammonia was adsorbed at room temperature and further desorbed in nitrogen flow at higher temperatures. The influence of the vanadium concentration in 


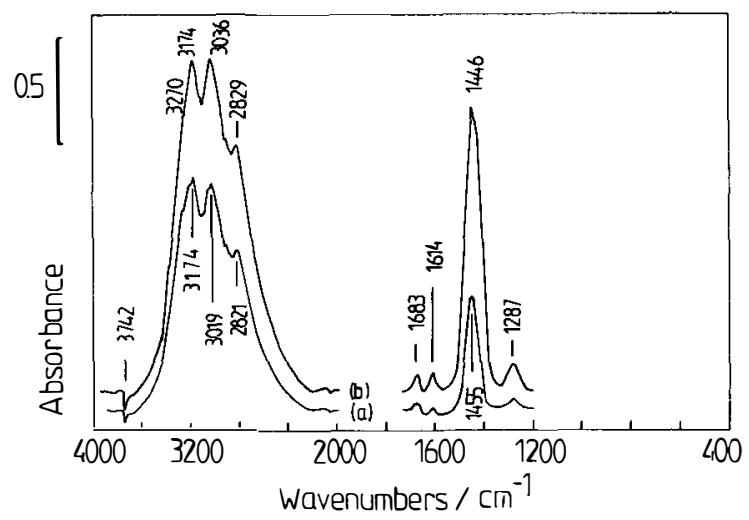

Fig. 7. DRIFT spectra of ammonia adsorption on $\mathrm{V}_{2} \mathrm{O}_{5} / \mathrm{SiO}_{2}$ catalysts: (a) 4.8 , (b) 19.1 wt.- $\%$ $\mathrm{V}_{2} \mathrm{O}_{5}$. Adsorption and desorption in nitrogen at $298 \mathrm{~K}$.

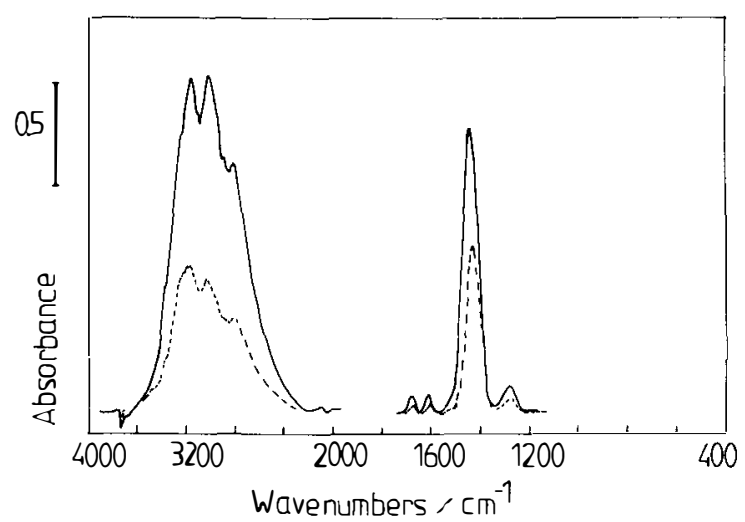

Fig. 8. DRIFT spectra of ammonia adsorption at $298 \mathrm{~K}$ on 19.1 wt.- $\% \mathrm{~V}_{2} \mathrm{O}_{5} / \mathrm{SiO}_{2}$. Desorption in nitrogen at $298 \mathrm{~K}$ (full lines) and $353 \mathrm{~K}$ (dotted lines).

the development of acidic features is depicted in Fig. 7. We have compared the DRIFT spectra after ammonia adsorption followed by desorption in nitrogen, both at room temperature, obtained for the 4.8 and $19.1 \mathrm{wt}$. $\% \mathrm{~V}_{2} \mathrm{O}_{5} / \mathrm{SiO}_{2}$ catalysts. The spectra can be well interpreted in connection with previous studied [19]. Both Lewis and Brønsted acid sites are detected. Vibrations at 1287 and $1614 \mathrm{~cm}^{-1}$ are ascribed to Lewis acid centers $\left(\delta_{\mathrm{S}} \mathrm{NH}_{3}, \delta_{\text {as }} \mathrm{NH}_{3}\right)$. Two other deformation modes at 1455 and $1683 \mathrm{~cm}^{-1}$ are attributed to Brønsted populations $\left(\delta_{\mathrm{as}} \mathrm{NH}_{4}^{+}, \delta_{\mathrm{s}} \mathrm{NH}_{4}^{+}\right)$and are connectèd to the broad stretching band at $3174 \mathrm{~cm}^{-1}$. The weak shoulder at $3270 \mathrm{~cm}^{-1}$ is usually ascribed to the stretching mode of ammonia coordinatively bound to the Lewis sites. Hydrogen of the adsorbate also interacts via the hydrogen bond with anions of the oxide. This 
interaction gives rise to the vibrations detected at 2821 and $3019 \mathrm{~cm}^{-1}$. No adsorbed species were observed on pure silica.

The strength of each acid type developed on the $19.1 \mathrm{wt} . \% \mathrm{~V}_{2} \mathrm{O}_{5} / \mathrm{SiO}_{2}$ catalyst is illustrated on Fig. 8. This figure displays the adsorbed species observed after desorption at 298 and $353 \mathrm{~K}$. It is difficult to assume that Lewis acid sites are stronger than the Brønsted acid sites. By desorption in nitrogen at $423 \mathrm{~K}$, adsorbed ammonia species were hardly detected.

Therefore, the fresh catalysts can be regarded as medium acidic materials. Both Lewis and Brønsted acid sites of similar strength are formed by the deposition of vanadium on silica.

Correlation between acidic features of $\mathrm{V}_{2} \mathrm{O}_{5} / \mathrm{SiO}_{2}$ catalysts and their catalytic activity

A usual concept is that selective oxidation of hydrocarbons involves both a redox cycle and acid-base site populations [19]. Fig. 9 depicts the rate of ethene formation and ethane conversion at $813 \mathrm{~K}$ versus the ammonia uptake on each catalyst. We have mentioned above that ethane conversion requires a minimal amount of vanadium atoms (see Fig. 2) and we have also showed a linear relation between the population of acidic sites and the $\mathrm{V}_{2} \mathrm{O}_{5}$ content of the catalysts (see Fig. 6). Therefore a linear relation between ethane conversion and acidic character of the $\mathrm{V}_{2} \mathrm{O}_{5} / \mathrm{SiO}_{2}$ surface is normally observed. This figure also indicates that an increase in acidic character does not lead to higher ethene selectivity.

We have also measured the acidity of some samples previously treated under an ethane-oxygen mixture. One selected $\mathrm{V}_{2} \mathrm{O}_{5} / \mathrm{SiO}_{2}$ catalyst $\left(19.1\right.$ wt.- $\% \mathrm{~V}_{2} \mathrm{O}_{5}$ ) was subjected to ammonia adsorption after a catalytic run in a microreactor, in order to investigate the modifications in the acidic aspect of the catalyst surface induced by the oxidative dehydrogenation of ethane. Before the ad-

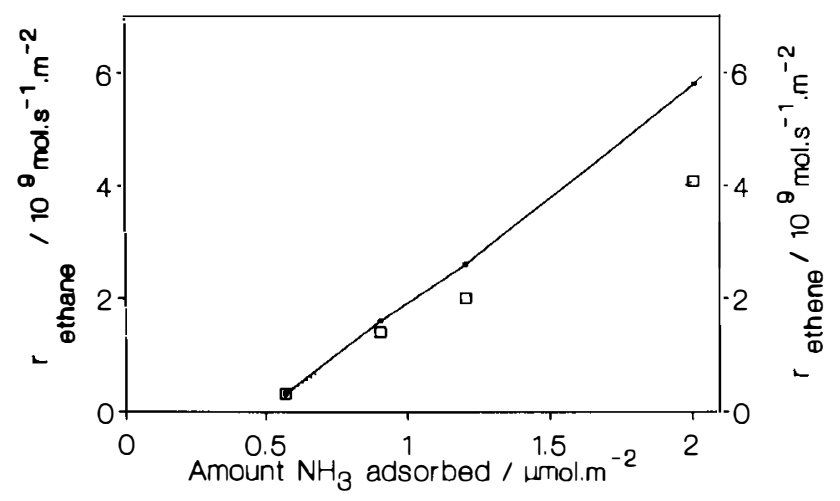

Fig. 9. Rate of ethane conversion (-口-) and ethene formation $(\cdot \cdot \square \cdot \cdot)$ as a function of the ammonia uptake of the $\mathrm{V}_{2} \mathrm{O}_{5} / \mathrm{SiO}_{2}$ catalysts prepared by wet impregnation. 


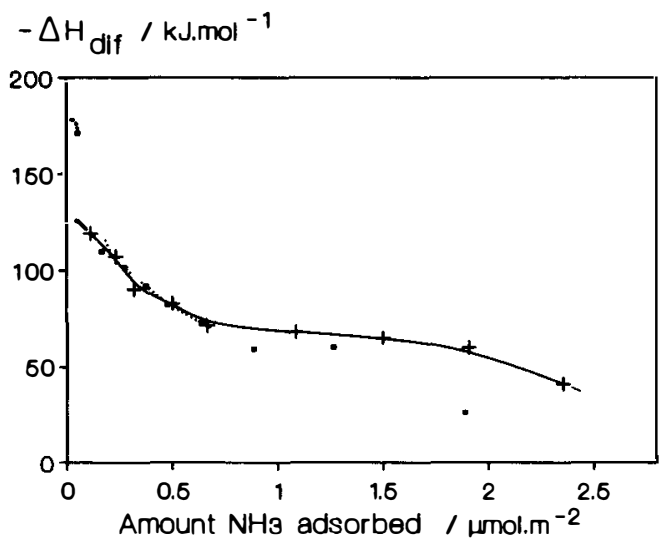

Fig. 10. Differential enthalpies of adsorption of ammonia at $353 \mathrm{~K}$ as a function of coverage on 19.1 wt.- $\% \mathrm{~V}_{2} \mathrm{O}_{5} / \mathrm{SiO}_{2}$ : fresh catalyst (full line), after catalytic reaction (dotted line).

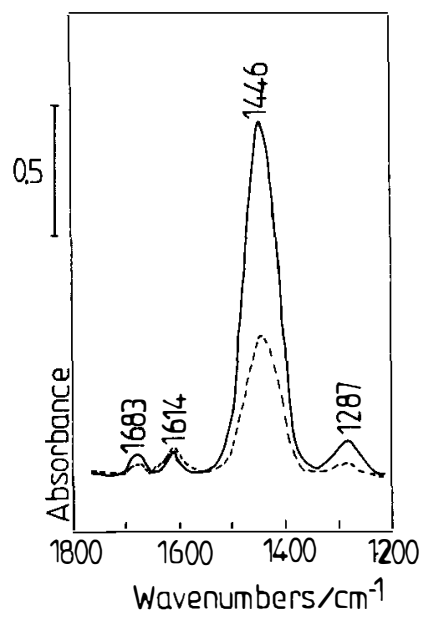

Fig. 11. DRIFT spectra of ammonia adsorption at $298 \mathrm{~K}$ on $19.1 \mathrm{wt} .-\% \mathrm{~V}_{2} \mathrm{O}_{5} / \mathrm{SiO}_{2}$ : fresh catalyst (full line), after catalytic reaction (dotted line).

sorption measurements, the catalyst was heated for $6 \mathrm{~h}$ at $803 \mathrm{~K}$ in an ethaneoxygen mixture with helium as diluent and was further outgassed at $673 \mathrm{~K}$ for 2 h. On Fig. 10 are compared the differential enthalpies of adsorption as a function of the ammonia uptake before and after a catalytic run. After catalysis, some weak acid sites have disappeared. Additional information about these modifications has been obtained from the associated adsorption isotherms. On the one hand, the ammonia uptake is $3 \%$ lower after a catalytic run. On the other hand, concerning the strongest acid sites, the relative gain in the ammonia uptake is ca. $10 \%$ after catalytic treatment. Only minor deactivation phenomena occurred during the catalytic treatment. Due to the loss of weak 
acid sites, the simultaneous adsorption equilibria of ammonia are modified, and the average values of the differential enthalpy of ammonia adsorption measured at low coverage increase. Further information concerning the acidic character of the used catalyst has been obtained following ammonia adsorption by DRIFT spectroscopy (Fig. 11). It was found that the Brønsted population was decreased after treatment under the reacting mixture. By contrast, the intensity of the vibration bands ascribed to the Lewis acidity did not vary appreciably. Thus under the ethane-oxygen reacting mixture, the surface of the $\mathrm{V}_{2} \mathrm{O}_{5} / \mathrm{SiO}_{2}$ catalyst was transformed. The limited loss of acid sites may be related to a minor deactivation of the catalyst and shows that our study on catalysts before reaction is reliable.

\section{CONCLUSION}

$\mathrm{V}_{2} \mathrm{O}_{5} / \mathrm{SiO}_{2}$ catalysts are selective for the oxidative dehydrogenation of ethane in ethene. Compared to bulk vanadium pentoxide, the overall catalytic activity is enhanced to a limited extent due to the low dispersion on silica, whatever the preparation method is. The catalytic activity increased with the vanadium content and the ammonia uptake of the $\mathrm{V}_{2} \mathrm{O}_{5} / \mathrm{SiO}_{2}$ catalysts, i.e. with their acidity. However, at the same conversion level, selectivity to ethene is improved for low vanadium loadings, corresponding presumably [28], to distorted vanadium tetrahedra, $\mathrm{VO}_{4}$, which are not present on bulk vanadium pentoxide and can be considered as medium acidic sites. Moreover, selectivity to ethene seems to be more related to the coordination of vanadium atoms than to the acidic character of the surface of $\mathrm{V}_{2} \mathrm{O}_{5} / \mathrm{SiO}_{2}$ catalysts.

\section{REFERENCES}

1 M.B. Ward, M.J. Lin andJ.H. Lunsford, J. Catal., 50 (1977) 306.

2 E.M. Thorsteinson, T.P. Wilson, F. G. Young and P.H. Kasai, J. Catal., 52 (1978) 116.

3 T.Y. Yang and J.H. Lunsford, J. Catal., 63 (1980) 505.

4 M. Iwamoto, T. Taga and S. Kagawa, Chem. Lett., (1982) 1469.

5 L. Mendelovici and J.H. Lunsford, J. Catal., 94 (1985) 37.

6 A. Argent and P.G. Harrison, J. Chem. Soc., Chem. Commun. (1986) 1058.

7 E. Morales and J.H. Lunsford, J. Catal., 118 (1989) 255.

8 S.T. Oyama and G.A. Somorjai, J. Phys. Chem., 94 (1990) 5022.

9 S.T. Oyama and G.A. Somorjai, J. Phys. Chem., 94 (1990) 5029.

10 A. Erdöhelyi and F. Solymosi, J. Catal., 123 (1990) 31.

11 M. Merzouki, B. Taouk, B. Monceaux, E. Bordes and P. Courtine, in P. Ruiz and B. Delmon (Eds.), New Developments in Selective Oxidation by Heterogeneous Catalysis, Stud. Surf. Sci. Catal., Vol. 72 Elsevier, Amsterdam, 1992, p. 165.

12 R. Burch and S.C. Tsang, Appl. Catal., 65 (1990) 259.

13 S.J. Conway and J.H. Lunsford, J. Catal., 129 (1991) 497.

14 R. Burch and R. Swarnakar, Appl. Catal., 75 (1991) 321.

15 A. Erdöhelyi and F. Solymosi, J. Catal., 129 (1991) 497. 
16 A. Erdöhelyi, F. Máté and F. Solymosi, Catal. Lett., 8 (1991) 229.

17 E.M. Kennedy and N.W. Cant, Appl. Catal., 75 (1991) 321.

18 B. Dadyburjor, S.S. Jewur and E. Ruckenstein, Catal. Rev. Sci. Eng., 19(2) (1979) 293.

19 R.A. Rajadhyaksha and H. Knözinger, Appl. Catal., 51 (1989) 81.

20 B. Jonson, B. Rebenstorf, R. Larsson and S.L. Andersson, J. Chem. Soc., Faraday Trans I, 84 (1984) 1897.

21 J. Haber and A. Kozłowska and R. Kozłowski, J. Catal., 102 (1986) 52.

22 T. Tanaka, H. Yamashita, R. Tsuchitani, T. Funabiki and S. Yoshida, J. Chem. Soc., Faraday Trans I, 84 (1988) 2987.

23 S.T. Oyama, G.T. Went, K.B. Lewis, A.T. Bell and G.A. Somorjai, J. Phys. Chem., 93 (1989) 6786.

24 J.M. López-Nieto, G. Kremenic and J.L.G. Fierro, Appl. Catal., 61 (1990) 235.

25 N.K. Nag and F.E. Massoth, J. Catal., 124 (1990) 127.

26 S. Yoshida, T. Igushi and K. Tamara, Bull. Chem. Soc. Jpn., 45 (1972) 376.

27 B. Taouk, M. Guelton, J. Grimblot and J.P. Bonnelle, J. Phys. Chem., 92 (1988) 6700.

28 O.B. Lapina, V.M. Mastikhin, A.V. Nosov, T. Beutel and H. Knözinger, Catal. Lett., 13 (1992) 203.

29 N.K. Nag, K.V.R. Chary, B.R. Rao and S. Subrahmanyam, Appl. Catal., 31 (1987) 73.

30 F. Roozeboom, M.C. Mittelmeijer, J.A. Moulijn, J. Medema, V.H.R. de Beer and P. Gellings, J. Phys. Chem., 84 (1980) 2783.

31 M. Schraml-Marth, A. Wokaun, M. Pohl and H.L. Krauss, J. Chem. Soc., Faraday Trans I, 87 (1991) 2635.

32 G.C. Bond and S. F. Tahir, Appl. Catal., 71 (1991) 1.

33 J. Le Bars, J.C. Vedrine, A. Auroux, B. Pommier and G.M. Pajonk, J. Phys. Chem., 96 (1992) 2217.

34 G.C. Bond and K. Brückman, Disc. Faraday Soc., 72 (1981) 235.

35 A. Auroux and J.C. Vedrine, in B. Imelik, C. Naccache, G. Coudurier, Y. Ben Taarit and J.C. Vedrine (Eds.), Catalysis by Acids and Bases, Stud. Surf. Sci. Catal., Vol. 20 Elsevier, Amsterdam, 1985, p. 311.

36 M. Del Arco, M.J. Holgado, C. Martín and V. Rives, Langmuir, 6 (1981) 801. 